\title{
Synthesis and Antibacterial Screening of 4-Arylidene- 5-oxo-imidazoles having Carboxamide Linkage with 5-(benzofuran-2-yl)-1-phenylpyrazole Moiety
}

\author{
MOHAMMAD IDREES $^{* 1}$ R. D. NASARE ${ }^{2}$ and N. J. SIDDIQUI ${ }^{1}$ \\ ${ }^{1}$ Department of Chemistry, Government Institute of Science, \\ Nagpur-440001, Maharashtra, India \\ ${ }^{2}$ Department of Chemistry, Government Science College, \\ Gadchiroli- 442605, Maharashtra, India \\ idreesshaikh.2009@gmail.com
}

Received 5 October 2016 / Accepted 10 October 2016

\begin{abstract}
Synthesis of 5-(H/Br benzofuran-2-yl)-1-phenyl $1 H$-pyrazole-3-carbohydrazides (1a-b) and condensation with different 4-(arylidene)-2 phenyloxazol-5(4H)-one (2a-g) in acetic acid medium, a series of 5-( $\mathrm{H} / \mathrm{Br}$ benzofuran -2-yl)- $N$-(4-arylidene-5-oxo-2-phenyl-4,5-dihydroimidazol-1-yl)-1-phenyl-1 $H$-pyrazole-3-carboxamide derivatives (3a-g) have been carried out. Different 4-(arylidene)-2-phenyloxazol-5(4H)-one (2a-g) were synthesized from substituted benzaldehyde with hippuric acid. The structures of the novel compounds were elucidated on the basis of elemental analysis and spectral studies such as FT-IR, ${ }^{1} \mathrm{H}$ NMR, further supported by Mass spectra. The synthesized 5-(benzofuran-2-yl)- $N$-(4-benzylidene-5-oxo-2-phenyl-4,5-dihydroimidazol1-yl)-1-phenyl-1 $H$-pyrazole-3-carboxamide (3a) was assayed in vitro for their antimicrobial activity at different concentration against four different bacterial strains namely $B$. thurengienesis, $S$. aureus, $E$. coli and $E$. areogenes. The investigation of antibacterial screening reveals that 3a exhibited excellent activity against Gram +ve and poor activity against Gram -ve bacteria when compared to chloramphenicol as standard drug.
\end{abstract}

Keywords: 5-Oxo imidazole, 4-Arylidene oxazolones, Carbohydrazides

\section{Introduction}

From last two decades many organic researchers have exposed synthesis of novel heterocyclic ring containing nitrogen as a hetero atom. Unlike pyrrole (a proton donor) and pyridine (a proton acceptor), $1 H$-imidazole has proton donor and acceptor properties ${ }^{1-2}$. Imidazole is well known common heterocyclic compound which is present in natural products and medicinal drugs. Imidazole nucleus is a biologically accepted pharmacophore. Many antifungal drugs like ketoconazole, miconazole, clotrimoxazole contains imidazole ring. Imidazole derivatives possess a broad spectrum of pharmacological activities such as antimicrobial and anthelmintic ${ }^{3}$, anticonvulsant ${ }^{4}$, antiparkinson ${ }^{5-6}$, anticancer and anti-HIV ${ }^{7,8}$, antiviral $^{9}, \mathrm{CNS}$ depression ${ }^{10}$. 
The compounds incorporated with 5-oxo-imidazoline are known to hold biological as well as chemical aspects since long time. 5-Oxo-imidazolines have been reported to exhibit a wide range of pharmacological activities including anticancer ${ }^{11}$, antihelminthic activity ${ }^{12}$, anti-

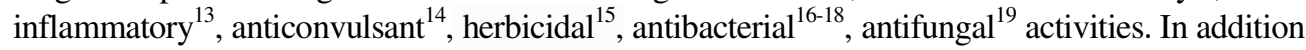
pyrazole ring also have great therapeutic importance and their derivatives showed excellent antiviral, anti-tumor ${ }^{20}$, anti-inflammatory, analgesic ${ }^{21}$, herbicidal ${ }^{22}$, insecticidal ${ }^{23}$ activities.

Searching of antibacterial agents with new structure and mode of action is an essential strategy of chemists and the therapeutic importance of these type of compounds. In continuation of our previous work inspired us to synthesize 5-oxo-imidazoles including 5-(benzofuran-2-yl)-1-phenyl pyrazole moiety and to evaluate their antibacterial activities against different bacterial strains.

\section{Experimental}

The melting points were recorded in open capillary in paraffin bath and are uncorrected. IR spectra were recorded on a Shimadzu IR Spectrophotometer $\left(\mathrm{KBr}, \mathrm{v}\right.$ max in $\left.\mathrm{cm}^{-1}\right)$. ${ }^{1} \mathrm{H} \mathrm{NMR}$ spectra are recorded on a Bruker AM 400 instrument using tetramethylsilane as an internal reference and DMSO- $\mathrm{d}_{6}$ as solvent. Chemical Shifts are given in parts per million. Positiveion Electro Spray Ionization (ESI) mass spectra were obtained with a Waters Micromass QTOF Micro, Mass Spectrophotometer. Elemental (CHN) analysis was done using thermo scientific (Flash-2000), the compounds were analysed for carbon, hydrogen and nitrogen and the results obtained are in good agreement with the calculated values. Chemicals used for the synthesis were of AR grade of Merck, S. D. Fine and Aldrich. The reactions were monitored by E. Merck TLC aluminum sheet silica gel ${ }_{60} \mathrm{~F}_{254}$ and visualizing the spot in UV Cabinet and iodine chamber.

To a mixture of 4-benzylidene-2-phenyloxazol-5(4H)-one (2a) $(0.498 \mathrm{~g}, 0.002 \mathrm{~mol})$ and 5-(benzofuran-2-yl)-1-phenyl-1 $H$-pyrazole-3-carbohydrazide (1a) (0.636 g, 0.002 mol), acetic acid $(20 \mathrm{~mL})$ was added and contents were refluxed for $9 \mathrm{~h}$. Resulting mass was poured onto crushed ice, filtered and the product was recrystallized from ethanol to give 3a.

Similarly, other 5-(5-bromobenzofuran-2-yl)- $N$-(4-Arylidene-5-oxo-2-phenyl-4,5dihydroimidazol-1-yl)-1-phenyl-1H-pyrazole-3-carboxamide derivatives 3b-g were synthesized from $\mathbf{1 b}$ and $\mathbf{2 b - g}$ by adopting the same procedure applied for $\mathbf{3 a}$.

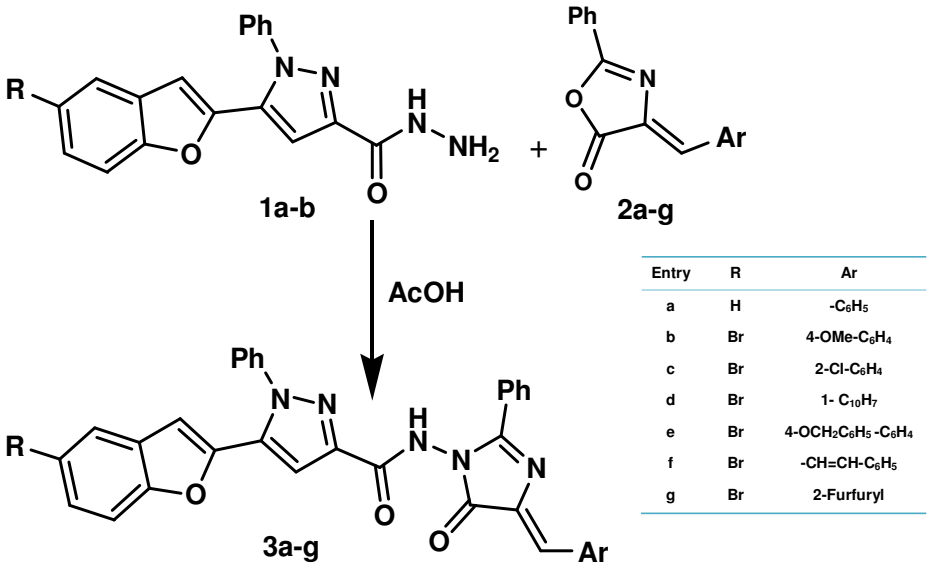

Scheme 1 
3a: Yellow crystalline solid; mp, 200-204 ${ }^{\circ} \mathrm{C}$; yield, 90\%; IR ( $\mathrm{KBr}, \mathrm{v}_{\max }$ in $\left.\mathrm{cm}^{-1}\right): 3197$ (N-H stretch), 3062 (C-H stretch in aromatic ring), 1793, 1719 (C=O stretch in imidazole), $1597,1525,1496,1448,(\mathrm{C}=\mathrm{C}$ stretch in aromatic ring ), 1207,1292,1028 (C-O-C stretch), 1164 (C-N-C stretch), 1692 (C=O stretch in secondary amide group), 1640, $1525(\mathrm{C}=\mathrm{N}$ stretch), $1110(\mathrm{C}-\mathrm{N}) .{ }^{1} \mathrm{H}$ NMR (DMSO-d $\left.\mathrm{d}_{6}\right) \delta(\mathrm{ppm}): 6.53$ (s, 1H, C4 of pyrazole ring), 11.65 (s, $1 \mathrm{H}, \mathrm{NH}$ of amide group), 7.22-8.37 (m, 21H, ArH + benzofuran ring). MS: $m / z 550[\mathrm{M}+\mathrm{H}]^{+}$, $551[\mathrm{M}+2]^{+}, 572[\mathrm{M}+\mathrm{Na}]^{+}, 573[(\mathrm{M}+\mathrm{H})+\mathrm{Na}]^{+}$.Elemental Anal. Calcd: for $\mathrm{C}_{34} \mathrm{H}_{23} \mathrm{~N}_{5} \mathrm{O}_{3} ; \mathrm{C}$, 74.30; H, 4.22; N, 12.74 Found: C, 74.16; H, 4.05; N, 12.37.

3b: yellow crystalline solid; recrystallization solvent, Ethanol; mp, 132-135 ${ }^{\circ} \mathrm{C}$; yield, 78\%; IR (KBr, $\mathrm{v}_{\max }$ in $\left.\mathrm{cm}^{-1}\right): 3315$ (N-H stretch), 3063 (C-H stretch in aromatic ring), 1779, $1720(\mathrm{C}=\mathrm{O}$ stretch in imidazole), 1502, $1438(\mathrm{C}=\mathrm{C}$ in aromatic ring), 1257, 998 (C-O-C stretch), 1159 (C-N-C stretch), 1693 ( $\mathrm{C}=\mathrm{O}$ stretch in secondary amide group), 1649, 1595 $\left(\mathrm{C}=\mathrm{N}\right.$ stretch), $1106(\mathrm{C}-\mathrm{N})$. Elemental Anal. Calcd: for $\mathrm{C}_{35} \mathrm{H}_{24} \mathrm{BrN}_{5} \mathrm{O}_{4} ; \mathrm{N}, 10.64$; Found: N, 10.03 .

3c: yellow crystalline solid; recrystallization solvent, Ethanol; mp, 155-158 ${ }^{\circ} \mathrm{C}$; yield, 82\%; IR ( $\mathrm{KBr}, \mathrm{v}_{\max }$ in $\left.\mathrm{cm}^{-1}\right): 3105(\mathrm{~N}-\mathrm{H}$ stretch), 1786, $1715(\mathrm{C}=\mathrm{O}$ stretch in imidazole), 1501,1433 (C=C in aromatic ring), 1243, 1060 (C-O-C stretch), 1155 (C-N-C stretch), 1689 $(\mathrm{C}=\mathrm{O}$ in amide group), 1643, $1595(\mathrm{C}=\mathrm{N}$ stretch), $1106(\mathrm{C}-\mathrm{N})$. Elemental Anal.Calcd: for $\mathrm{C}_{34} \mathrm{H}_{21} \mathrm{BrClN}_{5} \mathrm{O}_{3} ; \mathrm{N}, 10.56$; Found: $\mathrm{N}, 10.11$.

3d: yellow crystalline solid; recrystallization solvent, Ethanol; mp, 136-138 ${ }^{\circ} \mathrm{C}$; yield, $76 \%$; IR (KBr, $\mathrm{v}_{\max }$ in $\left.\mathrm{cm}^{-1}\right): 3051$ (N-H stretch), 3005 (C-H stretch in aromatic ring), 1778, ( $\mathrm{C}=\mathrm{O}$ stretch in imidazole), 1489, 1431 ( $\mathrm{C}=\mathrm{C}$ in aromatic ring), 1236, 1069 (C-O-C stretch), 1151 (C-N-C stretch), 1689 ( $\mathrm{C}=\mathrm{O}$ stretch in secondary amide group), 1593 (C=N stretch), 1151 (C-N). Elemental Anal. Calcd: for $\mathrm{C}_{38} \mathrm{H}_{24} \mathrm{BrN}_{5} \mathrm{O}_{3} ; \mathrm{N}, 10.32$; Found: N, 10.40 .

3e: yellow crystalline solid; recrystallization solvent, Ethanol; mp, 155-157 ${ }^{\circ} \mathrm{C}$; yield, 80\%; IR (KBr, $\mathrm{v}_{\max }$ in $\left.\mathrm{cm}^{-1}\right): 3133$ (N-H stretch), 3062, 2986 (C-H stretch in aromatic ring), $1786,1716(\mathrm{C}=\mathrm{O}$ stretch in imidazole $), 1501,1438(\mathrm{C}=\mathrm{C}$ in aromatic ring $), 1249,998(\mathrm{C}-$ O-C stretch), 1160 (C-N-C stretch), 1692 (C=O in amide group), 1642, 1595 (C=N stretch), $1110(\mathrm{C}-\mathrm{N})$. Elemental Anal.Calcd: for $\mathrm{C}_{41} \mathrm{H}_{28} \mathrm{BrN}_{5} \mathrm{O}_{4}$; N, 9.53; Found: N, 9.07.

3f: yellow crystalline solid; recrystallization solvent, Ethanol; mp, 158-160 ${ }^{\circ} \mathrm{C}$; yield, 84\%; IR (KBr, $\mathrm{v}_{\max }$ in $\left.\mathrm{cm}^{-1}\right)$ : 3054 (N-H stretch), 3034(C-H stretch in aromatic ring), 1783 $(\mathrm{C}=\mathrm{O}$ stretch in imidazole), 1493, 1439 ( $\mathrm{C}=\mathrm{C}$ in aromatic ring), 1237, 1068 (C-O-C), 1158 (C-N-C stretch), 1696 (C=O stretch in secondary amide group), 1597 (C=N stretch), 1105 (C-N). Elemental Anal.Calcd: for $\mathrm{C}_{36} \mathrm{H}_{24} \mathrm{BrN}_{5} \mathrm{O}_{3} ; \mathrm{N}, 10.70$; Found: N, 10.25.

3g: yellow crystalline solid; recrystallization solvent, Ethanol; mp, $148-150{ }^{\circ} \mathrm{C}$; yield, 83\%; IR $\left(\mathrm{KBr}, \mathrm{v}_{\max }\right.$ in $\left.\mathrm{cm}^{-1}\right): 3210(\mathrm{~N}-\mathrm{H}$ stretch), $3062(\mathrm{C}-\mathrm{H}$ stretch in aromatic ring), $1783(\mathrm{C}=\mathrm{O}$ stretch in imidazole $), 1496,1450(\mathrm{C}=\mathrm{C}$ in aromatic ring $), 1231,1008$ (C-O-C stretch), 1153 (C-N-C stretch), 1695(C=O stretch in secondary amide group), 1641, $1525\left(\mathrm{C}=\mathrm{N}\right.$ stretch), $1079(\mathrm{C}-\mathrm{N})$. Elemental Anal.Calcd: for $\mathrm{C}_{32} \mathrm{H}_{20} \mathrm{BrN}_{5} \mathrm{O}_{4} ; \mathrm{N}$, 11.32; Found: N, 10.96.

\section{Antibacterial activity}

The novel synthesized heterocyclic compound 3a was screened for their in vitro antimicrobial activity using cup plate agar disc-diffusion method against bacterial strains such as B. thurengienesis, S. aureus, E. coli and E. aerugenes. Chloramphenicol was used as standard drug for bacteria. 


\section{General procedure}

\section{Determination of zone of inhibition by agar disc-diffusion method}

Test solutions were prepared with known weight of compound in DMSO and half diluted suitably to give the resultant concentration of $31-1000 \mu \mathrm{g} / \mathrm{mL}$. Whatmann no. 1 sterile filter paper discs $(6 \mathrm{~mm})$ were impregnated with solution and allowed to dry at room temperature. In vitro antibacterial activity was determined by using Mueller Hinton Agar obtained from Himedia Ltd., Mumbai. Petri plates were prepared by pouring $10 \mathrm{~mL}$ of Mueller Hinton Agar for bacteria containing microbial culture was allowed to solidify. The discs were then applied and the plates were incubated at $37{ }^{\circ} \mathrm{C}$ for $24 \mathrm{~h}$ (bacteria) and the inhibition zone was measured in $\mathrm{mm}$ as diameter in four directions and expressed as mean. The results were compared against Chloramphenicol as a standard drug and are reported in the Table 1.

Table 1. Antibacterial Activity of 3a

\begin{tabular}{|c|c|c|c|c|c|}
\hline \multirow{3}{*}{$\begin{array}{c}\text { S. } \\
\text { No. }\end{array}$} & \multirow{3}{*}{$\begin{array}{l}\text { Conc. } \\
\mu \mathrm{g} / \mathrm{mL}\end{array}$} & \multicolumn{4}{|c|}{ Zone of Inhibition in $\mathrm{mm}$} \\
\hline & & \multicolumn{2}{|c|}{ Gram +ve } & \multicolumn{2}{|c|}{ Gram -ve } \\
\hline & & B. thurengienesis & S. aureus & E. coli & E. areogenesis \\
\hline \multicolumn{6}{|c|}{$\mathbf{3 a}$} \\
\hline 1. & 100 & 15 & 14 & 14 & 10 \\
\hline 2. & 500 & 14 & 12 & 10 & 12 \\
\hline 3. & 250 & 12 & 16 & 12 & 10 \\
\hline 4. & 125 & 18 & 12 & 15 & - \\
\hline 5. & 63 & 12 & 18 & 12 & - \\
\hline 6. & 31 & 10 & 15 & - & - \\
\hline \multicolumn{6}{|c|}{ Standard Chloramphenicol } \\
\hline 1. & 1000 & 22 & 26 & 24 & 16 \\
\hline 2. & 500 & 20 & 30 & 20 & 16 \\
\hline 3. & 250 & 21 & 27 & 18 & 17 \\
\hline 4. & 125 & 16 & 21 & 17 & 16 \\
\hline 5. & 63 & 15 & 18 & 17 & 15 \\
\hline 6. & 31 & 16 & 20 & 21 & 15 \\
\hline
\end{tabular}

\section{Results and Discussion}

The synthesis of the novel compounds 3a-g is described in the Scheme 1. The purity of the compounds was checked by TLC technique. The structure of the newly synthesized compound 3a was confirmed using different spectroscopic techniques such as IR, ${ }^{1} \mathrm{H}$ NMR, Mass and $\mathrm{C}, \mathrm{H}, \mathrm{N}$ analyses. Analytical and spectral data of 3a was in full agreement with proposed structure. 5-(H/Br benzofuran-2-yl)-1-phenyl-1 $H$-pyrazole-3-carbohydrazides (1a-b $)^{24}$ and 4-(arylidene)-2-phenyloxazol-5(4H)-ones (2a-g) were synthesized in quantitative yields by adopting the literature method ${ }^{25}$ and their confirmation were done on the basis of m.p. determination. Condensation of 1a-b with 4-(arylidene)-2-phenyloxazol-5(4H)-ones (2a-g) in acetic acid as a solvent afforded 3a-g.

IR spectrum of 3a showed absorption bands at $3197 \mathrm{~cm}^{-1}$ due to $-\mathrm{NH}$ stretching and disappearance of absorption band due to $-\mathrm{NH}_{2}$ stretching and appearance of two absorption bands at 1719 and $1692 \mathrm{~cm}^{-1}$ for two carbonyl group of amides indicated that 4(arylidene)-2-phenyloxazol-5(4H)-ones condensed with 5-(H/Brbenzofuran-2-yl)-1phenyl-1H-pyrazole-3-carbohydrazides. 
In ${ }^{1} \mathrm{H}$ NMR, all protons are seen in accordance to the expected chemical shift. The ${ }^{1} \mathrm{H}$ NMR spectrum of 3a showed singlet at $\delta 10.65 \mathrm{ppm}$ for $-\mathrm{NH}$ group and disappearance of signal due to $-\mathrm{NH}_{2}$ group in the formation of $\mathbf{3 a}$ which is expected as in carbohydrazide $\mathbf{1 a}$ and exhibited multiplet at $\delta 7.22-8.37 \mathrm{ppm}$ due to 21 aromatic protons which is in consistent with aromatic protons of prepared compound 3a. Its elemental analysis indicated percentage of $\mathrm{C}, \mathrm{H}$ and $\mathrm{N}$ are $74.16,4.05$ and 12.37 respectively. Its mass spectrum showed a molecular ion peak at $\mathrm{m} / \mathrm{z} 550$ $[\mathrm{M}+\mathrm{H}]^{+}$, which is in good agreement with the proposed structure and its molecular formula $\mathrm{C}_{34} \mathrm{H}_{23} \mathrm{~N}_{5} \mathrm{O}_{3}$. Similarly the structures of other synthesized compounds $\mathbf{3 b} \mathbf{b}$ g have been confirmed on basis of IR and elemental analysis data which is given in experimental.

\section{Antibacterial activity}

According to antibacterial data the test compound 3a at $125 \mu \mathrm{g} / \mathrm{mL}$ conc. showed excellent activity against $B$. thurengienesis while at rest of the concentrations it possesses good to moderate activity against Gram positive bacteria, B. thurengienesis and S. aureus. In case of gram negative bacteria $E$. coli and $E$. areogenes, the test compound showed poor activity. Test compound $3 \mathbf{a}$ was found to be inactive against $E$. areogenes at conc. $125,61,31 \mu \mathrm{g} / \mathrm{mL}$ while, it was inactive at conc. $31 \mu \mathrm{g} / \mathrm{mL}$ against $E$. coli.

\section{Conclusion}

A series of novel 5-oxo-imidazole derivatives (3a-g) were successfully synthesized in good yields. Their purity and confirmation was checked by physical, analytical and spectral data. Antibacterial screening of the synthesised compound 3a was found to possess good to moderate activity against selected strains of bacteria.

\section{Acknowledgement}

The authors are thankful to The Principal, Government Science College, Gadchiroli, for his support and cooperation. The authors are also thankful to Dr. S. D. Narkhede, Head, Department of Botany, GSC, Gadchiroli for permitting to carry out the antimicrobial activity, similarly the authors are also thankful to The Director, SAIF, Punjab University, Chandigarh for providing CHN analysis, IR, ${ }^{1} \mathrm{HNMR}$ and Mass Spectra.

\section{References}

1. Foster E J, Lavigueur C K and Williams V E, J Mater Chem., 2005, 15, 4062-4068; DOI:10.1039/B503310A

2. Brunsveld L, Zong H, Glasbeek M E W and Meijer E W, J Am Chem Soc., 2000, 122(26), 6175-6182; DOI:10.1021/ja0005237

3. Sharma A, Kumar V, Kumar S and Pathak D P, Bull Pharm Res., 2016, 6(1), 21-27.

4. Upadhyay P S, Joshi H D, Baxi A J and Parikh A R, Iidian J Heterocycl Chem., 1991, 1, 21-27.

5. Naithani DK, Srivastava V K, Barthwal J P, Saxena A K, Gupta T K and Shanker K, Indian J Chem., 1989, 28(B), 990.

6. Miyachi H, Kiyota H and Egawa M, Bioorg Med Chem Lett., 1998, 8(14), 1807 1812; DOI:10.1016/S0960-894X(98)00312-6

7. Shah B R, Bhatt J J, Patel H H, Undavia N K, Trivedi P B and Desai N C, Indian J Chem., 1995, 34(B), 201-208.

8. Krezel I, Farmaco, 1998, 53 (5), 342.

9. Sharma D, Narasimhan B, Kumar P, Judge V, Narang R, Clercq E D and Balzarini J, Eur J Med Chem., 2009, 44(6), 2347-2535; DOI:10.1016/j.ejmech.2008.08.010 
10. Meenakshi S, Reena K, Renu S, Dixit K S, Nath C and Barthwal J P, Indian J Chem., 1990, 29(B), 85.

11. El-Hady H A and Abubshait S A, Res Chem Intermed., 2015, 41, 1833; DOI:10.1007/s11164-013-1464-x

12. Maneshwar T, Vijethal N, Balakrishna V, Kumar Ch V and Suresh M, Int J Pharm., 2014, 4(1), 437-441.

13. Kalluraya B, Gunaga P, Banji D and Isloor A M, Bollettino Chimico Farmaceutico, 2001, 140(6), 428-432.

14. Moorthy N S, Saxena V, Karthikeyan C and Trivedi P, J Enz Inhib Med Chem., 2012, 27(2), 201-207.

15. Wepplo PJ, Pest Sci, 1990, 29(3), 293-315; DOI:10.1002/ps.2780290306

16. Biplab De, Jayanta K G and Venkatapuram S S, Acta Pharm., 2005, 55(3), 287-296.

17. Desai N C, Bhavsar A M and Baldaniya B B, Indian J Pharm Sci., 2009, 71(1), 90-94.

18. Omar A M and Nada M A, Hamdi M H, Ahmad S and Abu Samaha M, Int J Chem., 2011, 3(4), 20-32.

19. Mohd A, Arun K, Israr A and Khan S A, Indian J Chem., 2009, 48, 1288-1293.

20. Park H, Lee K, Park S, Ahn B, Lee J, Cho H and Lee K, Bioorg Med Chem Lett., 2005, 15, 3307-3312; DOI:10.1016/j.bmcl.2005.03.082

21. Sung H, Karen M, Aaron T and Bruce D, J Med Chem., 2011, 54(8), 3037-3050; DOI:10.1021/jm2001376

22. Wu H, Feng J, Lin K and Zhang X, Molecules, 2012, 17(10), 12187-12196; DOI:10.3390/molecules171012187

23. Fu C, Pei J, Ning Y, Liu M, Shan P, Liu J, Li Y, Hu F, Zhu Y and Yang H, Pest Manag Sci., 2014, 70(8), 1207-1214; DOI:10.1002/ps.3672

24. Siddiqui N J, Idrees M, Khati N T and Dhonde M G, Bull Chem Soc Ethiop., 2013, 27(1), 85-94; DOI:10.4314/bcse.v27i1.9

25. Furniss B S, Hannaford A J, Smith P W G and Tatchell A R., Vogel's text book of practical organic chemistry, $5^{\text {th }}$ Edn., Longman Group, Essex, UK. 1989. 